\title{
The micro leadership strategy of the principal to implementing character education in elementary school
}

\author{
Daniel Dike *, Lusila Parida \\ STKIP Persada Khatulistiwa Sintang. Jalan Pertamina Sengkuang Km 4, Sintang, 78614, Indonesia \\ * Corresponding Author. Email: dikedanieltukan@gmail.com
}

Received: 18 April 2020; Revised: 11 May 2020; Accepted: 26 May 2020

\begin{abstract}
The micro strategy in the character education is very decisive for successfully developing and empowering the character values in the elementary school degree. With reference to the statement, the objective of the present study is describing the micro strategy management in implementing the character education within the elementary school. Thus, the design that has been adopted is the case study and the data for the case study are gathered from the primary sources through interview, observation, and documentation study. After the data had been gathered the, data were analysed by using the Miles \& Huberman Inductive Analysis. The results of the study show that the micro strategy of the school principal leadership in the Sekolah Dasar Negeri 07 Sintang have been focused on four aspects namely: (1) the reinforcement of literacy; (2) the learning intervention; (3) the program of Ant Operation; and (4) the extracurricular programs. In order to maintain the four aspects, the elementary school should deepen and expand the concept and the coverage of the literacy, improve the capacity of leading practice and teaching practice through the blended learning model, and also improve the capacity of the school management system through the integrated quality system and service.
\end{abstract}

Keyword: micro strategy, value empowerment, management capacity improvement

How to Cite: Dike, D., \& Parida, L. (2020). The micro leadership strategy of the principal to implementing character education in elementary school. Jurnal Prima Edukasia, 8(1), 51-66. doi:https://doi.org/10.21831/jpe.v8i1.29920

\section{Introduction}

The reflective leadership of a school principle refers to a directed reflection and action toward the development of the character education prominence in the elementary school degree throughout Indonesia. The development and the achievement of the educational quality within the elementary school degree will be realized if the important components from the aspects of quality are empowered as parts of the prominent characters. In order to arrive at this end, the strategic role and position of a school principal in designing, implementing, organizing, and evaluating the programs of character education hold an important role toward the assurance of well-qualified system and service within the elementary school degree.

The implementation of good micro strategy management is highly decisive for the creation of the employment conditions and encourages the positive learning performance within the classrooms as the epicentre for the learning process of the character values. The good micro strategy management by the school principal encourages the stability of the school organization and assures the availability of the classroom infrastructure and technology in order to ease the objective achievement and the educational benefits of the character education in the school (Kostelnik et al., 2012). This matter is important in order to deal with the tendency of the school members, who are still highly dependent on what the leader has said or on the orders that the superior has instructed. The micro strategy management can be a factor of critical success in all educational levels and subjects from the perspective of perception level, value awareness, and strategic actions from all of the school members, starting from the school principal to the teachers, the staffs, and eventually the students (Dike \& Parida, 2016, 2019; Ozkan et al., 2009).

The strategic management of the school principal can be creatively manifested through the reinforcement and the empowerment of the micro strategy management. However, it should be understood that, on the one hand, the micro strategy can turn into an excessive act of intervention by the school 
Jurnal Prima Edukasia, 8 (1), 2020 - 52

Daniel Dike, Lusila Parida

principal when the micro strategy is not properly handled. On the other hand, however, the micro strategy can turn into a stimulus of interaction, communication, collaboration, and network reinforcement in order to manifest a transformative and empowering leadership management. The balanced integration between the micro strategy and the macro strategy within the leadership management of the school principal can ease the achievement of the character education idealism within the school.

The orientation of the school principals up to date are generally more focused toward the aspects of leadership and management at the macro level and, consequently, the school principals pay less attention to the empowerment of the micro strategy management; therefore, there should be a balance between the aspects of policy and the aspects of implementation in relation to the programs of character education within the school. According to Aristoteles, in order to support the reinforcement of character education in the school the competence of practical wisdom should be reinforced (Ryan \& Bohlin, 1999). This competence refers to good deeds or the practical wisdom within the leadership. In the implementation of character education, the practical wisdom is simply manifested in the form of the school principal's capacity in leading and directing the teachers, the staffs, and the students on three key aspects namely knowing the good, loving the good, and doing the good, which are very suitable to be developed on the level of the school principal (Ryan \& Bohlin, 1999).

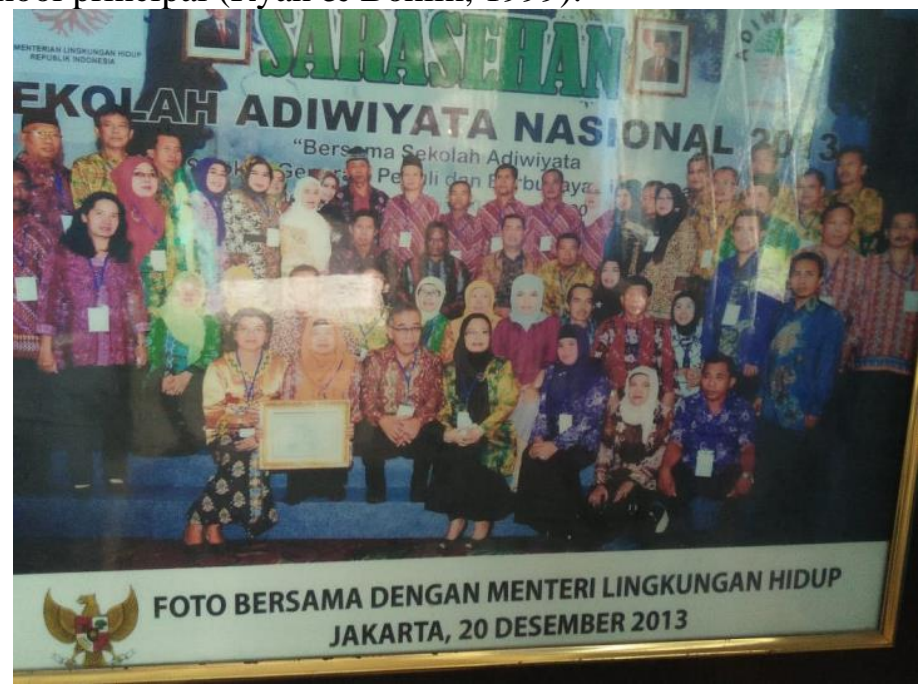

Figure 1. SDN 07 as the participant of the National Level Healthy School Competition and won the Sekolah Adiwiyata Award from the Ministry of Environment in 2013

Theoretically, both the school principals and the teachers have a great opportunity within the implementation of the character education in the school because socially the elementary school students have several points of prominence with regards to their social behaviours. In general, the elementary school students have positive mood; they usually attend the activity programs voluntarily and, in fact, they show their empathic capacity. At the same time, the elementary school students also have positive relationship with their peers show their high sense of humour (Kostelnik et al., 2012). The prominence of the social potentials that the elementary school students have can be a starting point for the school principal to design the micro strategy management in order to support the implementation of the character education through the elementary school curriculum (Setyawan \& Mustadi, 2015). In fact, the development and the reinforcement of the prominent character values should be started as early as possible as the form of the school commitment in building the students' characters from the most fundamental degree (Qodriyah \& Wangid, 2015).

In relation to the above elaboration, the classical problem that all elementary schools have been dealing with in the level of school principal leadership within the hinterland of the Regency of Sintang is the absence of the micro strategy capacity empowerment. The focus of the leadership up to date has been more narrowed on the implementation of the instructional management; consequently, the micro strategy that includes numerous aspects of quality, such as the management of financial resources and other resources, for advancing the creation of the culture of innovation and creativity are less properly handled.

The peculiar prominence of the SDN 07 Sintang as the reference of Adiwiyata since 2011 has encouraged the research to take an in-depth observation and portray the management of micro strategy

Copyright (c) 2020, Jurnal Prima Edukasia, ISSN 2338-4743 (print), ISSN 2460-9927 (online) 
Jurnal Prima Edukasia, 8 (1), 2020 - 53

Daniel Dike, Lusila Parida

that has been developed in the elementary school. With reference to the statement, the objective of the study is to portray the micro strategy of the school principal strategy within the implementation of the character education, to identify the meaning of the experience, and to offer an integrative model of the micro strategy management for the implementation of the character education in the elementary school so that the school principal will be enabled to maximize the overall action in accordance with the information that has been gathered from the external environment in the level of macro leadership (Alshamsi, 2017).

\section{Method}

The study adopted the case study research design. The consideration of using the case study research design was that the study had been intended to serve as a medium of emic research. The dimension of emic research within the study was uncovering the inside part of the people and the indigenous meanings of the real-world events. Specifically, the study was intended to uncover something actual from the perspective of potential interactive context within the encounter between the researchers and the informants or the research subjects (Olive, 2014; Yin, 2009). Thus, in the study the objective was to present the experiences of the school principal, the teachers, and the students as the subjects who had direct and unique experiences in relation to the implementation of the character education within the school. This approach was compatible to the characteristic of the one-case study in which the subjects under the study had both situational peculiarity and data elaboration that had been completely presented in accordance with the actual experiences within the daily life from each subject (Ary et al., 2018; Stake, 2005).

\section{Location and Period}

The study was conducted in the SDN 07 Sintang, West Borneo. The location of the study was selected by using the area purposive sampling technique. Then, the study itself took place in the even semester of the 2018/2019 Academic Year and the odd semester of the 2019/2020 Academic Year.

Subjects

As having been previously explained, the subjects were selected by using the purposive sampling method. Then, the subjects who had been selected for the study were 1 school principal, 10 teachers namely the homeroom teachers and the student-activity advising teachers, 1 staff, and 12 students from six parallel classrooms ( 2 students from each classroom). The school principal was selected as the subject of the study because he held the authority to implement the micro strategy management within the school. Then, the teachers were selected under the consideration that they had played the role as both the homeroom teachers and the actors of the character values learning process. Furthermore, 1 staff was selected the staff had performed the administrative function of the school in relation to the implementation of the character education programs. Last but not the least, 12 students represented the other students as the subjects in relation to their involvement within the implementation of the character education. Specific to the students as the subjects in the study, these students were selected as the respondents of the study by paying attention to the gender equality, the ethnicity, the religion, and the involvement of the students within the learning process.

Data, Instrument, and Data Gathering Technique

The data were gathered by means of in-depth interview with the school principal in relation to the micro strategy management of the character education. In this case study, the researchers integrated numerous data that had been gathered from the observation, the interview, and the documentary study in order to elaborate the practice of the micro strategy management in accordance to the social context of the school through numerous valid data resources (Jansen, 2010, p.6). The centre of observation was the activities of the school principal, the teachers, and the students within the learning process. Several classrooms were selected randomly in order to view the practice of the character education within the school. Afterward, the findings from the auto observation were compared to the results of the interview and the documentary study by means of data display and triangulation process so that the findings were useful in achieving the in-depth insight with regards to the essential meaning and experience from the perspective of the micro strategy management that had been developed by the school principal in relation to the character education (Denzin \& Lincoln, 2011). 
Jurnal Prima Edukasia, 8 (1), 2020 - 54

Daniel Dike, Lusila Parida

\section{Data Analysis Technique}

The results of the in-depth interview and the observation were summarized and then were carefully reviewed in order to minimize the irrelevant information. Then, the subjects or the participants in the study were asked to confirm the conclusions from the interview transcripts and the observation, which had been summarized, in order to confirm the accuracy and reinforce the level of the data validity and the consistency (Dike \& Parida, 2019). All of the data that had been retrieved from both the in-depth interview and the observation had both direct and indirect observation so that the level of the data accuracy and the data reliability could be improved (Ary et al., 2018). Furthermore, the aspects that became the units of analysis were the school principal, the teachers, and the students because all of these subjects became an important part and were interrelated within the micro strategy management in the school 1 . The overall data presentation and data analysis thus led to a single conclusion that could be inductively drawn (Baxter \& Jack, 2008, pp. 554-555).

\section{Results and Discussions}

Results

The micro strategy that has been afforded by the School Principal of SDN 07 Sintang in relation to the implementation of the character education was formulated in the oral and written policy. The implementation of the character education within the SDN 07 Sintang as the reference sources from the vision of the elementary school namely Faithful, Prominent, and Noble. With reference to the statement, the elementary school has 10 important missions that should be implemented in the character education process namely: (1) appreciating religious teachings; (2) celebrating the religious festival days; (3) showing tolerance; (4) mastering the science and technology; (5) pursuing teacher professionalism through both formal and non-formal education; (6) developing the sports, the units of student activities, the boy scout unit, the art, and the skills; (7) delivering special service to the talented, intelligent, and less capable students; (8) holding cooperation and commitment toward the creation of the beautiful, healthy, and maintained learning environment; (9) preventing the environmental pollution; and (10) pursuing the greening and the care toward the living environment.

The implementation of the school vision and mission is manifested into the routine programs and activities of the elementary school and also into the programs of character reinforcement with little innovation in relation to the situational needs of the elementary school within the implementation of the character education programs in the five main domains of priority for the character education. Then, during in-depth interview and observation process, several interesting matters are found to be the important aspects within the character education program. These interesting matters will be elaborated further in the following sub-sections.

\section{Character reinforcement by means of 15-minute literacy and role model by teachers}

The SDN 07 Sintang implements the 15-minute literacy program by paying attention to the programs from the Central Government through the Ministry of Education and Culture in accordance with the Ministry of Education and Culture Regulation Number 23 of 2015. The important point within the process of school literacy in the SDN 07 Sintang lies in the courtesy development and the national character education reinforcement in the schools. This program becomes the activity that has been performed everyday in the school. The 15-minute literacy is contemplated as the individual and collective reading time for the students in the opening part of the everyday learning process for every classroom.

The 15-minute literacy becomes one of the compulsory alternatives in the micro strategy for opening the space to the creation of academic freedom in the classrooms. The micro strategy in the learning process enables the teachers and the homeroom teachers to improve the students' reading interest and literacy skill by using the reading materials that have been available in the classroom reading corner, the reading materials that the teachers afford creatively, or the reading materials that have been available in the school library (Figure 2).

The literacy activities in the classroom become the focus of the programs for reinforcing the core competence in the domain of the students' spiritual, social, knowledge and skills aspects within the thematic learning process. Within the observation toward the literacy activities in each classroom, the teachers or the homeroom teachers in general hold simultaneously the direct coordination in all classrooms at the beginning of the learning process in the morning. The meaning that has been attained from

Copyright (C) 2020, Jurnal Prima Edukasia, ISSN 2338-4743 (print), ISSN 2460-9927 (online) 
Jurnal Prima Edukasia, 8 (1), 2020 - 55

Daniel Dike, Lusila Parida

the 15-minute literacy activities is the manifestation of the students' efforts in exercising their reason, sense, and intention. In this regard, literacy refers to the programs of reasoning exercise that assists the opening of the students' insights and perspectives that have been developed in accordance to the themes and the character values that have been emphasized on each theme or sub-theme of the thematic learning process. The homeroom teacher of VIA explained that:

"The literacy activities at the beginning of the class help developing the students' critical thinking skills and exercising the students to be accustomed to encouraging themselves in raising questions and also uncovering and identifying the answers for the questions that appear in the reading materials that they read. On the contrary, the task of the teachers is to bring the students into the value awareness and understanding that has been developed through the in-depth questions, the understanding reinforcement, and the novel knowledge that have been internalized within the literacy process."

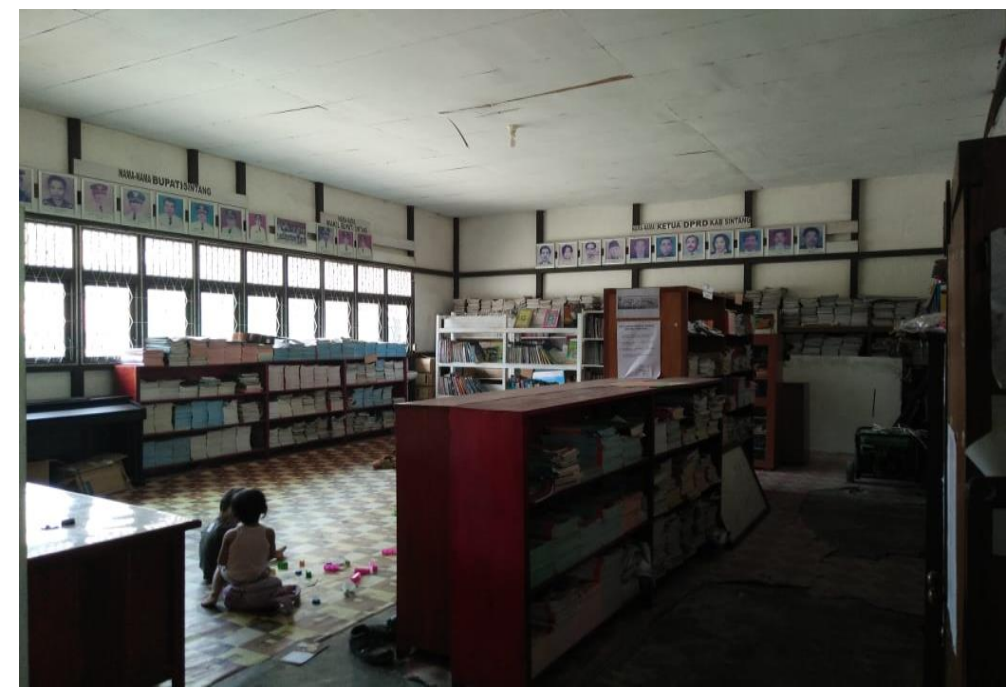

Figure 2. School library as the source and the place of the students' literacy process

The stimulation in the form of the questions that the students and the teachers have developed within the literacy process creates a huge opportunity for the creative process so that each student will be habituated to communicate through the oral and written manner, which results are displayed in the wall magazine of the school (Figure 3). The 15 minute-literacy strategy has assisted the students in developing the fundamental skills that have been expected by the 2013 Curriculum known as 4C (communication, collaboration, creativity, and critical thinking).

The literacy pattern in each classroom is generally quite conventional with the reading and question-and-answer method. According to the school principal, the four aspects $(4 \mathrm{C})$ and the 18 character values have been afforded by the elementary school as the important element within the programs of character values reinforcement. However, the evaluation of the thematic learning literacy process show that the aspects of creativity and critical thinking skills have not been maximally performed. In the interview, the school principal elaborated the conditions and the situations of the learning process that the elementary has dealt with:

"The aspects of creativity and critical thinking skills have not maximally developed by the teachers because the curriculum loadings that have been full of thick materials and also limited time allocation and reading materials have caused the teachers to be less able to fully accommodate the process of creativity and higher order thinking skills. The reason is that the teachers' orientation is to pursue the internalization of the thick learning materials; at the same time, most of the teachers have not been experienced yet in using the scientific approach. Consequently, changing the mindset of the teachers themselves is not easy since the mindset alone has not been compatible to the demands of the curriculum. However, it is in this limited situation that the teachers have afforded their best and I have encouraged them to keep learning and to be unafraid and unashamed of pursuing innovation."

The micro strategy management of the learning process by the school principal has also been afforded through the simple literacy activities such as the role of the teachers and the school members in displaying the wise words over the classroom and the terrace of the classroom. The objective of this initiative is to motivate and stimulate the students' knowledge and mental awareness to identify the good

Copyright (C) 2020, Jurnal Prima Edukasia, ISSN 2338-4743 (print), ISSN 2460-9927 (online) 
Jurnal Prima Edukasia, 8 (1), 2020 - 56

Daniel Dike, Lusila Parida

deeds and share the kindness. The stimulation of the wise and inspirational words does not only provide the space of collective memories but also develop the aspects of the role modelling by the teachers or the adults, including the parents or the guests who visit the school. The wise words such as "They can do it, certainly I can do it too!" (Figure 4a) and "This life does have an end but don't end yourself with drugs. Mark these words!" (Figure 4b) are the examples of the literacy process that motivate the students and these wise and inspirational words have been developed by the teachers in the SDN 07 Sintang in order to internalize the character values.

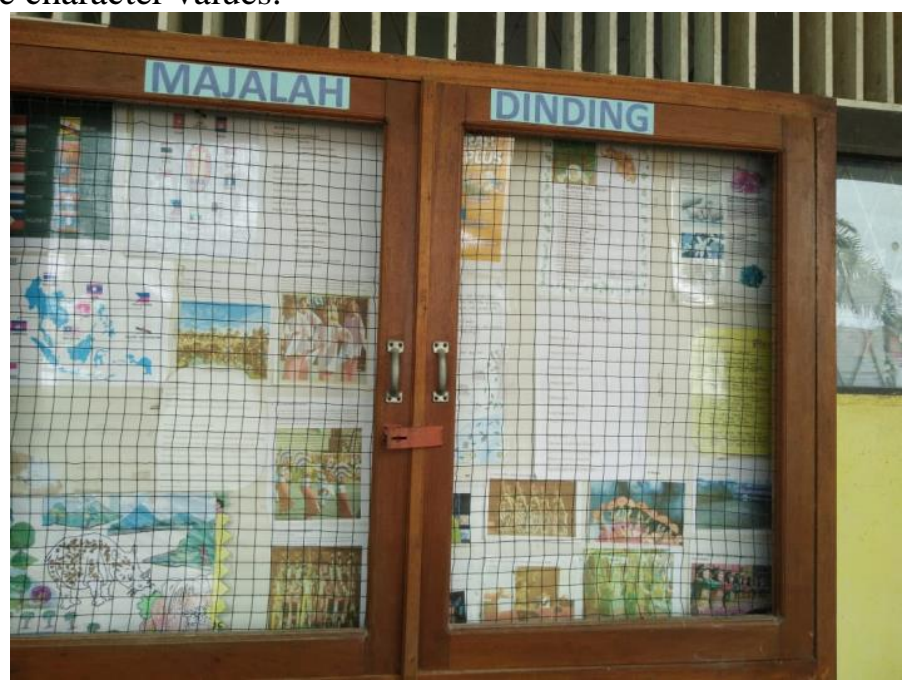

Figure 3. The results of the students' innovation that has been published in the elementary school's wall magazine

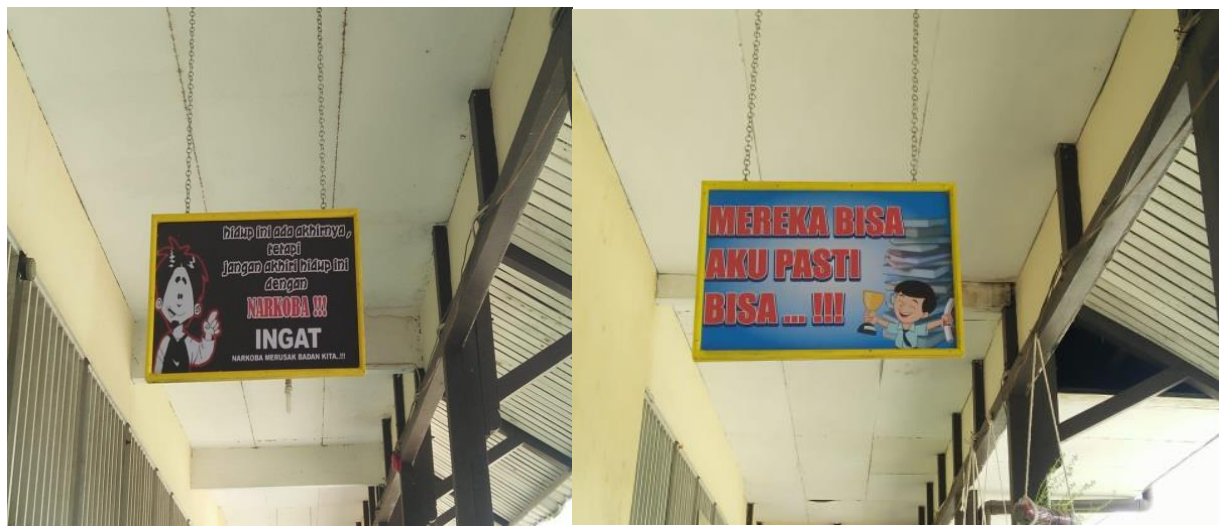

Figure 4. The motivation words as the part of the literacy and habituation process for the prominent character values in the elementary school; these words are hanging upside down over the ceiling in the alley of each classroom.

The habituation of the character values and the success of the literacy programs are determined by the attitude of consistency and role model among the teachers themselves in front of the students. According to the school principal, the teachers should be the role model for the importance of discipline, hard-work, diligence, responsibility, and also achievement and aspiration pursuance as the ultimate end of the students' learning process. This aspect is apparent from several displays of wise words over the wall and on the terrace of each classroom in the SDN 07 Sintang. Some of the wise words that describe the values of role model in the process of value habituation through literacy can be found in the following expressions:

"(1) I come, I study, and therefore I become intelligent; (2) if they can do it, then I can do it too; (3) this life do have an end but do not end your life with drugs; (4) throw the garbage to the garbage can; and (5) healthy, beautiful, and well-maintained environment."

In order to the reinforce the aspects of the teacher's role model, a number of trophies, certificates, and awards from one period of time to another are displayed in the school principal office as part of the school mission implementation in relation to the development of the achievement culture and the 
Jurnal Prima Edukasia, 8 (1), 2020 - 57

Daniel Dike, Lusila Parida

peculiar talent development for the students with the bright intelligence and the poor economic background. Indeed, there has been a space for the development and the improvement of the students' peculiar interest and capacity. The phenomenal object and achievement value become the history of achievement that provides educational values for the students. Every student who enters the teacher office and the school principal office will find the message of life and the pictures of the students' achievement, the certificates, and also the trophies that have been displayed. This factual reality delivers the message that the culture of achievement is one of the character values that encourage and inspire both teachers and the students.

Every school member is demanded to keep the good name of the SDN 07 Sintang as the Adiwiyata-referenced school. In order to support the vision and the mission of an elementary school with well-qualified characters, the elementary school principal has cooperated with the elementary school committee to procure more school facilities in the domain of Sports and these facilities are: (1) basketball court; (2) futsal court; and (3) badminton court. The procurement of these sports facilities is part of the school's efforts in developing the dimension of Sports. The dimension of Sports is one of the character values that encourage the establishment of the students' physically healthy and strong personality.

The micro strategy management of the school principal that preserves the culture of achievement is an important part of the quality system literacy that has always been promoted in the elementary school. The culture of achievement itself is an important part of the character reinforcement program with reference to the five priority of character reinforcement programs namely: (1) religious; (2) nationalist; (3) independent; (4) having integrity; and (5) upholding communalism. The socialization and the habituation of the character values in the SDN 07 Sintang has been pursued since the students enter the school. Several billboards and flowcharts that compose and describe the vision, the mission, and the motto of the elementary school are displayed over the school wall and on the school yard as part of the collective memories with regards to the importance of internalizing the prominent character values. In the implementation, all teachers work hand in hand by setting the schedules for organizing the fluency of the learning activities during the whole week. The teachers' role and duty are assigned by the school principal in order to assist his work in keeping the organization of the teaching-learning activities in the school under control.

The micro strategy by means of learning approach intervention

The leadership micro strategy of the school principal in the SDN 07 Sintang is implemented through the character learning approach that has been emphasized by the 2013 Curriculum. From the results of the observaion and the in-depth interview, it is found that the scientific approach has been conceptually developed by the teachers since the preparation of the lesson plans. Every theme and subtheme is equipped with an emphasis on the minimum character values from the lesson plan. In general, the teachers has brought quite creative media in the classroom in accordance with the capacities and the technological skills that they have mastered. In addition, the teachers' creativity has also developed although the creativity of the teachers has been limited to the use of almost uniform medium such as manila paper, styrofoam (for creating mindmap), decorations, and collage. Furthermore, in each classroom the works from the Art and Culture projects and also several display tools that the students have created from woods, dried leaves, plastic bottles, and plastic can also be found (Figure 5).

According to the record of the school principal, in general the senior teachers are mostly less technology-friendly in using computers and Internet and therefore the creativity in using the media and the teaching materials among these senior teachers are limited to the textbooks that have been available in the schol. The learning process for the Technology and Information skills among the senior teachers is difficult to internalize although some of the senior teachers strive to learn preparing their teaching materials by using the MicroSoft PowerPoint software and the LCD Projector that has been available in the school.

The development of the scientific approach for the teachers within the learning process has not been creatively performed by the teachers. The activities of exploration, observation, discussion, collaboration, and teamwork have not been habituated as part of the learning process that has been demanded by the 2013 Curriculum. In general, the implementation of the learning process returns to the individual knowledge, experience, and skills of the teachers. On the contrary, one or two junior teacher strives to perform small innovation and experiment because they have special skills although these skills are not 
Jurnal Prima Edukasia, 8 (1), 2020 - 58

Daniel Dike, Lusila Parida

related to the operation of computer technology. For example, in the Natural History the students' activities such as observing the plants in relation to the photosynthesis process, observing the types of plants around the school, and performing experiments about the light energy are performed by using the media that the teachers have designed outside the classroom. Such experience of limited sources has been complained by many teachers in many schools. With reference to the statement, the results of the studies in several regions also confirm that there are still many teachers who have been well-trained and who have not mastered the skills related to the thematic-integrative approach within the 2013 Curriculum (Muryaningsih \& Mustadi, 2015). The phenomena that have taken place in most schools show that the teachers' skills and understanding have been minimum and consequently they have difficulties in implementing the thematic-integrative approach within the school. With regards to the situation, the school principal explained that:

"For the implementation of the scientific approach or the other methods that emphasize creativity and critical thinking skills, we need the skills and the experiences of the teachers so that the implementation can be effectively pursued. When I was in Australia for three weeks under the BRIGE Programs, I found that the teacher skills and the classroom infrastructure readiness are heavily decisive for the learning quality and the teacher capacity in designing the learning process in the classroom. The teachers in Australia are not burdened with the heavy administrative works and therefore they can focus themselves on the learning innovation."

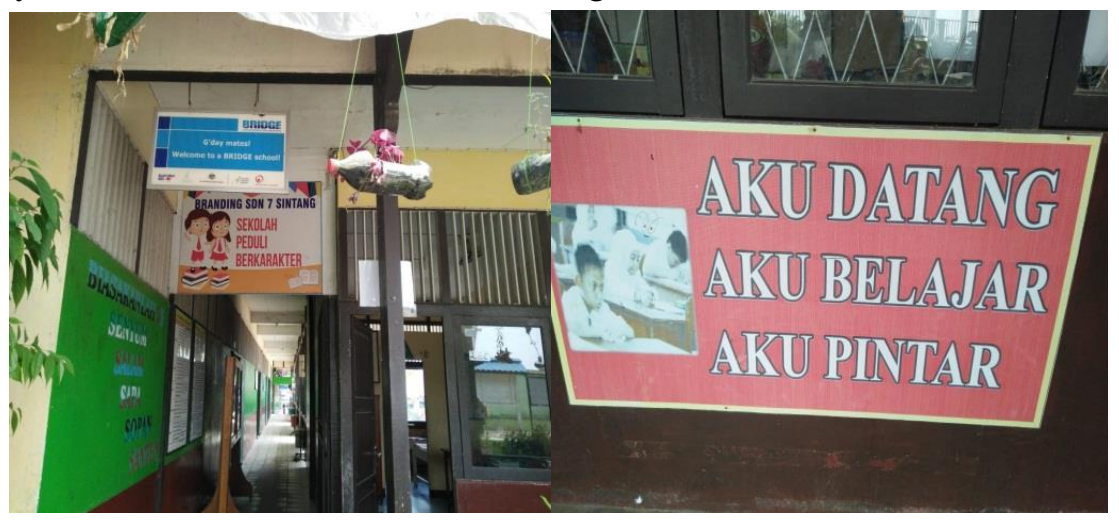

Figure 5. The motto of SDN 07 Sintang, a School of Compassion toward Characters, that has been displayed over the ceillings of the classroom terrace, the promotional board of BRIGE Australia Institution with the line: "Welcome to te Bridge School," and the motivational words artworks by the students over the styrofoam displayed in the classroom.

In general, the characters or the culture of innovation has been in the teachers' understanding but the characters or the culture of innovation have not been prominent yet as the culture of educational quality in Indonesia. The statement is confirmed by the results of PISA 2018, which place the Indonesian students on the $70^{\text {th }}$ rank of 78 countries in the domain of Science (Organization for Economic Cooperation and Development, 2019). The PISA results indeed show that the thematic learning process of the 2013 Curriculum has not been maximally empowered. With reference to the statement, the results of a research in the City of Pare-Pare, South Celebes show that both the thematic learning process and the thematic learning process by means of certain development model such as the Subject-Specific Pedagogy has significantly influenced the establishment of the character values in the elementary school (Masnur, 2017). The implication of the statement is that when the learning characters have been established since Grade 1 of elementary school degree there will be wide impacts on the development of the literacy skills within the domain of Mathematics, Science, and Language. In order to achieve this end, teacher empowerment should be regularly and continuously instead of partially and temporarily performed in the form of one-day training with the limited quota by the Office of Education. The reason is that not all teacher have the equal opportunity to attend the seminar and, in fact, the seminar or the workshop itself is not equally provided to all teachers from all domains. In relation to the organization and monitoring process of the teacher activities in the 2013 Curriculum, the school principal explained that:

"There are still some difficulties for the learning process implementation and evaluation in relation to the project and product assessment because the learning process implementation and evaluation 
Jurnal Prima Edukasia, 8 (1), 2020 - 59

Daniel Dike, Lusila Parida

require a lot of time and fund. As a result, this competence becomes the homework for the elementary school. However, in the future, we would like to collaborate with the Office of Education, higher education institutions, and quality assurance institutions in order to encouraged the programmed teacher empowerment.

Technically, the teacher learning process assessment in the classroom is afforded through the monitoring and the inspection toward the readiness of the learning instrument namely: (1) syllabus; (2) lesson plan; (3) media; and (4) method. Then, the school principal routinely implements the function of direct supervision to each classroom in order to ensure that the learning activities have been properly performed. The general evaluation is held in every semester by inviting and involving the role of active participation by all teachers.

\section{The micro strategy of habituating the cleanliness through the Ant Operation Movement}

The Ant Operation Movement is an internal policy of the elementary school that requires every student and teacher to pick up the garbage in their classroom or around the schoolyard every time they come early to school or whenever they leave the school. This strategic action implies that all school members have the morale responsibility to keep and to take care of the school environment cleanliness from the very first time they enter the elementary school. In an interview session, the homeroom teacher of Grade IVB stated that:

"The ant operation movement is actually a casual movement and can be done by many elementary schools. However, what makes the movement in SDN 07 Sintang different than the one in any other elementary school is the consistency and the role model that the school members have displayed; even the parents who visit their children in this elementary school is required to take care of the school cleanliness."

The statement has been supported by the homeroom teacher of Grade VA, who stated that:

"Whenever the parents enter pass the school gate, they are reminded to take care of the school cleanliness by the billboard hanging over the school gate such as: (1) "Throw the garbage to the can"; and (2) "The school is free of smoke." The entry point for the campaign of the clean and healthy school is teaching every student to maintain the personal cleanliness and the environmental cleanliness since literacy is one of the priority values in the SDN 07 Sintang as the elementary school of Adiwiyata."

In order to reinforce the early value habituation, the micro strategy that can be related to the implementation of the character value education is the Clean Friday Program. The Clean Friday Program is a program with the values of communalism that encourage the school members to Program to jointly pursue the school cleanliness and healthiness. The cleanliness and the healthiness should be applied in the form of concrete action in order to encourage the collective awareness among the school members. Personal and environmental cleanliness is part of the prominent values in the SDN 07 Sintang; the personal and environmental cleanliness has indeed delivered the SDN 07 Sintang to win the award of Healthy in 2002, the Healthy School Competition at the Province Level in 2011, and the Adiwiyata National in 2013 from the Ministry of Environment.

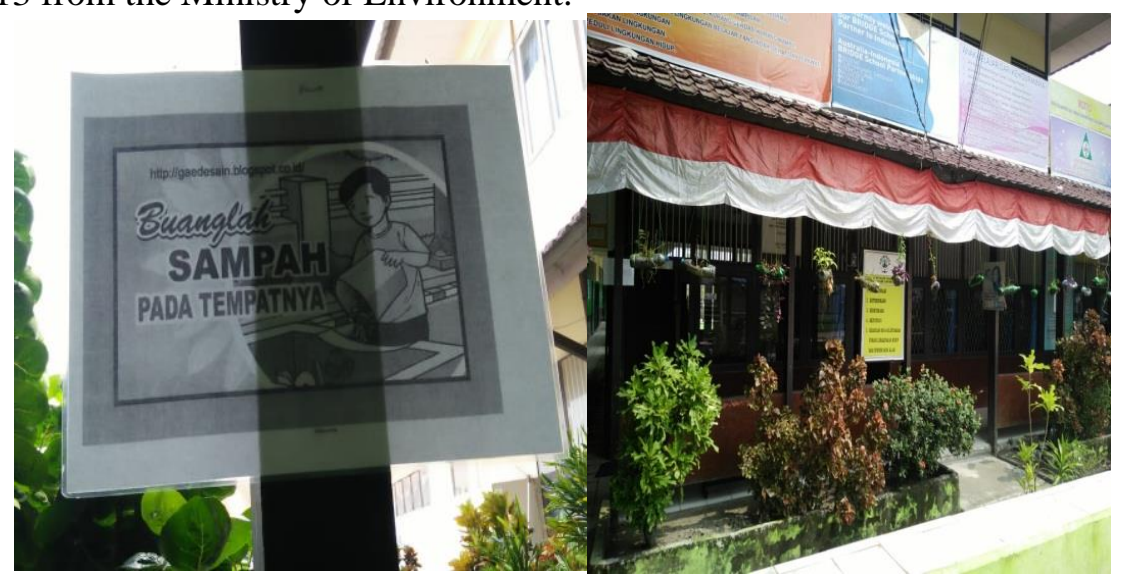

Figure 6. The suggestion to throw the garbage to the garbage can has been emphasized ever since the visitors pass the school gate through the small poster displayed on the concrete pole.

Copyright (C) 2020, Jurnal Prima Edukasia, ISSN 2338-4743 (print), ISSN 2460-9927 (online) 
Jurnal Prima Edukasia, 8 (1), 2020 - 60

Daniel Dike, Lusila Parida

The process of value and attitude education and habituation toward the appreciation of personal and environmental cleanliness is not solely limited to the routine activities in the SDN 07 Sintang; instead, the process has been developed into the culture of cleanliness, healthiness and green environment as the character values that should be internalized to the students. Every garbage can has been categorized based on the type of the garbage namely the plastic-based garbage and the paper-based garbage and the students have been accustomed to the garbage to its respective can. In addition, on the school front yard the slogan and the suggestion to throw the garbage on the garbage can have been emphasized. The slogan and the suggestion themselves have also been decorated by flowers and their vases in order to highlight the message of maintaining the school environment cleanliness (Figure 6). The culture of cleanliness and healthiness is one of the character values that have been developed as the concrete efforts of the elementary school in establishing the collective awareness on the clean and healthy life.

\section{The micro strategy by means of extracurricular activities development}

The extracurricular program dealing with the focus on the intention exercise has been accommodated by the boy-scout activities and the compulsory student interest development initiative for all students in accordance with the elementary school mission in developing the students' peculiar talent and interest. Every Saturday morning, the boy-scout activities take place from 07:00 until 08:10 Central Indonesian Time, followed by the thematic learning process or the prayer activities for the Christian or the Catholic students. Then, the art and culture extracurricular program has been integrated into the thematic learning process in relation to the topic of each sub-theme that the teachers have developed. Then, the extracurricular program that used to be developed is learning to play pianica. This extracurricular activity is possible to develop because there is a teacher who has experience in and training programs of Art in Yogyakarta and this is very helpful for the extracurricular activity development. On the other hand, the dance extracurricular activity has been assigned to the part-time teacher due to the absence of the full-time teacher. In this regard, the micro strategy policy is implemented by accessing the art galleries that have been funded by the parents of each student. In sum, it can be inferred that the problems of the extracurricular activities in the domain of Art and Culture within the elementary school is the absence of dance teacher and choir instructor.

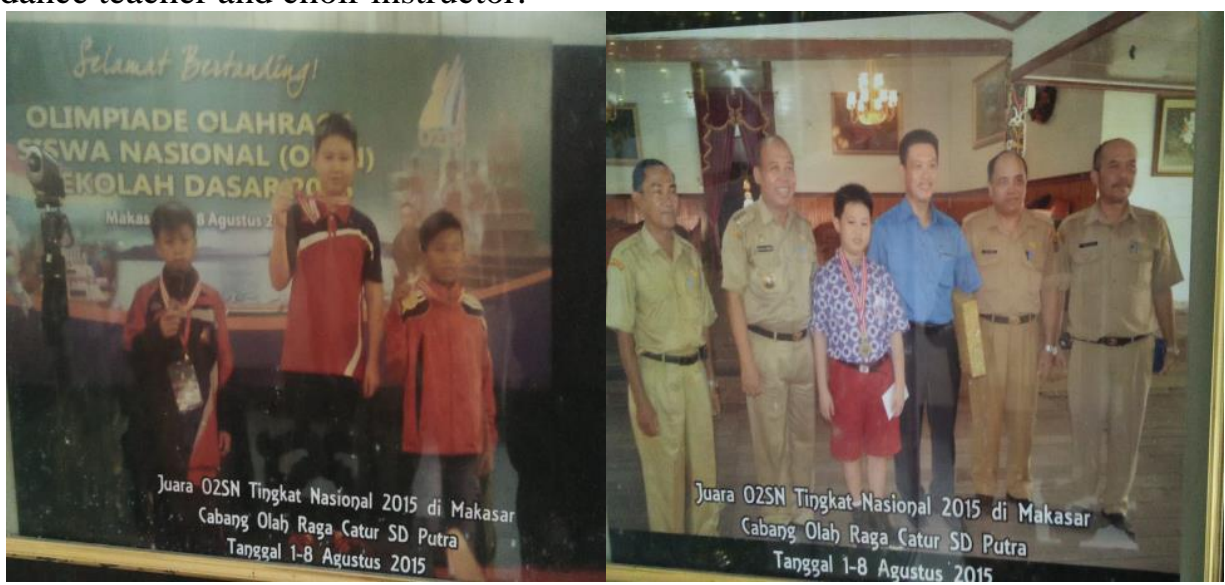

Figure 7. The student of SDN 07 Sintang who won the National Chess Game 2013 in the City of Makassar, South Sulawesi; the achievement of the student was appreciated by regional government and was awarded by the Regent of Sintang Drs. Milton Crosby, M.Si.

In the domain of Sports, the elementary school has prepared several sports facilities such as futsal court and basketball court (under construction) with the funding from the school committee. The special interest group such as traditional martial arts (pencak silat) and karate has been attended by the respective students. Similar situation also applies to the other domain of sports. For example, with regards to badminton the elementary school has established partnership with the Branch of Indonesian Badminton Federation in Sintang in order to accommodate the students' talent and interest in this sport. Then, the school principal explained that the character values that can be developed from the sports activities are cooperation, obedience, hard work, strength, discipline, communalism, independence, and sportsmanship. With regards to the statement, the micro strategy that has been defined for the character education in the domain of Sports is focused more on the event of the National Elementary School 
Jurnal Prima Edukasia, 8 (1), 2020 - 61

Daniel Dike, Lusila Parida

Student Sports Game. In addition, the parents are also provided with the opportunity to independent accommodate the talent and interest of their children outside the school period. In this case, the form of the independent involvement by the parents can be in the form of contributing to the students' special interest development. For example, one of the students in SDN 07 Sintang once won the First Place of the National Chess Competition 2013 held in the City of Makassar, South Celebes (Figure 7).

Discussions

In this section, four important aspects from the findings in the study will be discussed further.

\section{Implementing the culture of literacy as the efforts of brightening the students}

The 15-minute literacy as part of the micro strategy in the learning process can actually be expanded by using the more creative and meaningful learning literacy activities. Although the 15 -minute reading process has been routinely performed, the elementary school still has to expand the process and the coverage of the literacy in the overall learning process and activities. It is still insufficient for the teacher to rely on the 15-minute literacy activities in the classroom because the nature of these activities is only a stimulus from the perspective of the curriculum. Therefore, the school principal should define the micro strategy at level of the teacher learning process by expanding the innovation of the literacy program such as the literature literacy, the science literacy, and the history literacy that can be integrated into the co-curricular activities and the extracurricular activities. For example, the elementary school can expand the literacy activities by benefitting the school library, the reading corner, and the School Reading Park to create artworks such as scrapbook and wall magazine that the students should routinely display in each classroom. The reason is that the 15-minute literacy activities is actually an effort to shape the students' reading interest and culture. The reading and storytelling culture is very important in developing the students' intelligence. Einstein once stated, "if you want your children to be intelligent, read them fairy tales, if you want them to be more intelligent, read them more fairy tales" (Edarabia, 2019). The statement clearly imply that reading is a decisive factor that determine the level and the advancement of a student's intelligence and, consequently, it will be very good if the culture of literacy has been internalized well and has been expanded by using the appropriate methods and media in the elementary school. With reference to the statement, it is clear that through the use of the appropriate method the students' capacity can be fluently improved. In this regard, the micro strategy for the literacy learning process can be expanded and deepened by developing the art of role play, drama, music, and movie review. This kind of strategy can even be further implemented into monthly program, trimester program, semester program, and even annual program by collaborative preparing a team of teachers through partnership with both the universities and the public and private art galleries in order to develop the school literacy activities through more creative and meaningful manner.

\section{Implementing learning intervention for reinforcing the leading practice and the teaching practice}

The expansion and the deepening of the literacy in the classroom has assisted the teachers in delivering the students to the actual events and situations so that the students are capable to gain meaning from each life event that they experience individually since children genetically possess extraordinary potentials of development in terms of critical understanding and moral awareness (Dyson \& Millward, 2000; Gusarova, 2015; Hudha et al., 2019). Therefore, the school principal should intervene the learning process in order to reinforce the aspects of leading practice and teaching practice (Spillane et al., 2001). Both the school principal and the teachers should realize that the learning process in the classroom is a wide, complex, dan multidimensional practice. The complexity of the learning process is apparent from the number of questions that the students raise, the teaching materials that have been used in the learning process, and the ways in which the students interact with both themselves and the other students, including the classroom management that the students have developed.

Viewing the learning process in the classroom as a multidimensional practice will motivate the students to think about the relationship between the instructional leadership and the instructional innovation that they have developed. With reference to the statement, the micro strategy of the school principal is reinforcing the instructional leadership of the teachers by using the program targets for achieving the prominent character values such as discipline, creative, intelligent, caring, religious, nationalist, showing integrity, and communal; all of these values are indeed the outcome of the character education. The achievement of these character values can involve the role of the parents. The capacity 
Jurnal Prima Edukasia, 8 (1), 2020 - 62

Daniel Dike, Lusila Parida

of leading practice and teaching practice that that the teachers have reinforce their professionalism within the development and the expansion of the teaching materials, the teaching method and model variation, and the participatory evaluation. This reinforcement will be supported by the capacity of using the technological resources as the way for changing the behaviours of the students through the use and the delivery of the educational service (Masino \& Niño-Zarazúa, 2016). Although most of the elementary school teachers do not have the well-defined learning materials specialization and do not work within the situations in which the learning process is well-organized by the structure and the leadership of the school principal, the teachers are required to support the identify of their learning materials since the learning materials are part of the importat context for the teaching practice of character values in the elementary school (Schulte, 2008, p. 14).

The micro strategy management innovation through the learning process intervention can be developed through the blended learning concept. Such process of digital literacy should be developed especially during the pandemic of COVID-19 nowadays; furthermore, both the students and the teachers will be assisted in the 4.0 Industrial Revolution era when such process of digital literacy has been integrated into the school programs. Therefore, it is important for the school principal to get around the changes and the development of new science and skills that can be transferred to both the working environment and the learning environment for the teachers and the students in the school (Blaine, 2019, p. 34; Hilliard, 2015, p. 172). Therefore, the leadership capacity of the school principal should be reinforced by using the performance management system (Zbar et al., 2007). The reinforcement of the micro strategy management performance system can be pursued by benefitting numerous learning manners in relation to the literacy programs as having been offered by Barret namely: (1) inviting the students to talk by raising interesting an critical questions; (2) allocating storytelling time and joint authorship among the students in order to encourage the language awareness; (c) using technology wisely through virtual collaboration; and (D) ensuring that the students retrieve consistent message and turn the school environment as an environment rich of reading materials (Barrett \& Riddell, 2016).

\section{Building the culture of pursuing clean life and maintaining healthy environment}

The culture of clean and healthy life is the most important part of the fundamental character values which internalization has been required among the students both individually and collectively within the school community (mini society). The Ant Operation movement and the culture of green and healthy school are the calling and the the mission of the school in promoting the culture of appreciating the surrounding nature and environment as an inseparable ecosystem within the human life. Thus, destroying the environment means destroying human life. Therefore, environmental literacy becomes an important aspect within the character education because essentially education for the elementary school degree aims at fully developing the personality and striving to develop the school members with healthy body and mind as having been inspired by qualities that the students need in creating and building the peaceful and democratic citizens and society (Kyosoku \& Sei, 2009).

With regards to the previous paragraph, the character education in the elementary school can be categorized into two important aspects namely: (1) one-hour allocation per week for the moral education or the moral knowing classtime; and (2) provision of numerous moral education exercises through concrete practice or moral action. The culture of clean and healthy life, as well as the other character values, should accomodate both the weekly theory and the weekly practice in the school. The school activities that have been related to the internalization of character values should be under the general supervision of the teachers so that the core of the modal education activities can be delivered. It should be understood that the learning process in the classroom, or also known as classtime, reflects the theoretical framework of the well-structured teachers in their teaching activities; as a result, the teachers' understanding toward the character education represents the belief of the implicit cultures (Tobin et al., 2009). Then, the teachers' belief can be disseminated to the community of educational practitioners and can also be socialized through the development of their professionalism with the other teachers in the elementary school so that a tradition of good moral culture within the elementary school can be established. Thereby, the teachers will more able to develop the students' personality harmoniously as an independent, physically healthy, legally subject to the governing law and justice, human rights and self-esteem-appreciating, and also jobs and duties-appreciating citizens (Gusarova, 2015). The teachers should have an understanding that morality is not only a matter of setting principles or regulations but also defining the embedded matters in the "nuance" of traditions and expectations for guiding the 
Jurnal Prima Edukasia, 8 (1), 2020 - 63

Daniel Dike, Lusila Parida

students' behaviours. People with prominent character values in the practice tend to possess intuitive intuition from the words or the actions that are in accordance with the important situations. Aristoteles views that noble people are the ones who hold "the right feeling in the right time with the right reason toward the right persons for the right motif and in the right manner" (Gaskarth, 2012).

\section{Extracurricular reinforcement for the development of the students' talent and interest}

The extracurricular activities that have been routinely performed in the SDN 07 Sintang are Boy Scout and Sports. In general, the Boy Scout puts more emphasis on marching exercises and the basic skills of Boy Scout, which are usually prepared for the camping events. Usually, the Boy Scout activities involve the participation of the parents in facilitating the accomodation and the supervision. However, with regards to the Boy Scout activities, there is a prominent difference in the context of Indonesian education. The Boy Scout activities in the context of Indonesian education are more inclined to the Western education rather than the Japanese education, which has the special hours of moral or known as hours of morality. The extracurricular activities for the elementary school degree in Japan is held by using numerous teaching materials and activity types namely: (1) reading short stories; (2) reading poems; (3) composing articles; (4) watching educational videos; (5) listening to audio types; (6) performing interviews; (7) holding performance; (8) performing presentation; and (9) holding children attraction with creative performance through arts, movies, and drama (Gusarova, 2015).

The development of the extracurricular activities in the SDN 07 Sintang has been well-performed; however, these extracurricular activities have not been well-programmed yet with the loadings on the behaviour, talent, and interest development. Then, with regards to the statement, the support from the sufficient funding and the experienced teaching team are highly decisive for the continuance of the Boy Scout programs and the other extracurricular activities. Specific in this context, the talent and interest approach is still related to the daily routines in accordance with the teaching schedules and this approach has not been maximized in accordance with the needs of the special capacity, talent, and interest in relation to the mission of the elementary school. The achievement of some students, such as the one in the national level championship, is more of the parents' full and independent support. However, the National Students Olympic Games has tried to facilitate the students' talent and interest in the elementary school. This event does not only serve as a project-oriented semester or annual agenda by the elementary schools and the Office of education but also serve as a medium of empowerment and nursery for the students' potentials. In relation to the statement, the Indonesian teachers should learn from the serious attitude of the Japanese government's attention toward their educational process, which has taken place for centuries. The Japanese government views that the government's attention serves as the prerequisite for the achievement of the educational level quality and becomes a model of commitment that should be adopted by the other countries (Gusarova, 2015).

By placing the extracurricular activities as the medium of character development in the domain of the students' talent and interest, the school ecosystem should be rearraged in order to support all of the students' extracurricular activities. The elementary school should rearrange their working space and environment (the school space) and the students' activity environment so that the students can be familiar with their classroom. The culture of teacher collaboration should always be developed in order to facilitate the encouragement and the feedback that build the level of the students' imagination and creativity (Bamkin, 2016, p. 23). Therefore, the school infrastructure or the technology infrastructure should be integrated into the characters of the school quality. The elementary school should be equipped with the good sports facilities, specifically the sports facilities that give assurance to the fulfillment of the students' diverse talent and interest such as: (1) art performance stage or mini auditorium; (2) swimming pool; (3) martial arts facilities; (4) music facilities; and (5) sports facilities.

Several elementary schools have attempted the micro strategy implementation by benefitting the extra-school facilities such as swimming pool and soccer field. Certainly, this kind of action is not prohibited but from the aspects of practicality, budget, time efficiency, security, and accomodation it can be a problem for the teachers, the students, and the parents. In this kind of situation for the context of Indonesia, and specifically for the context of the Regency of Sintang, the capacity of the leadership micro and macro management becomes highly important to be internalized by the school principal. The capacity of the micro strategy is highly decisive for the transformation of educational quality and character development in the elementary school. 
Jurnal Prima Edukasia, 8 (1), 2020 - 64

Daniel Dike, Lusila Parida

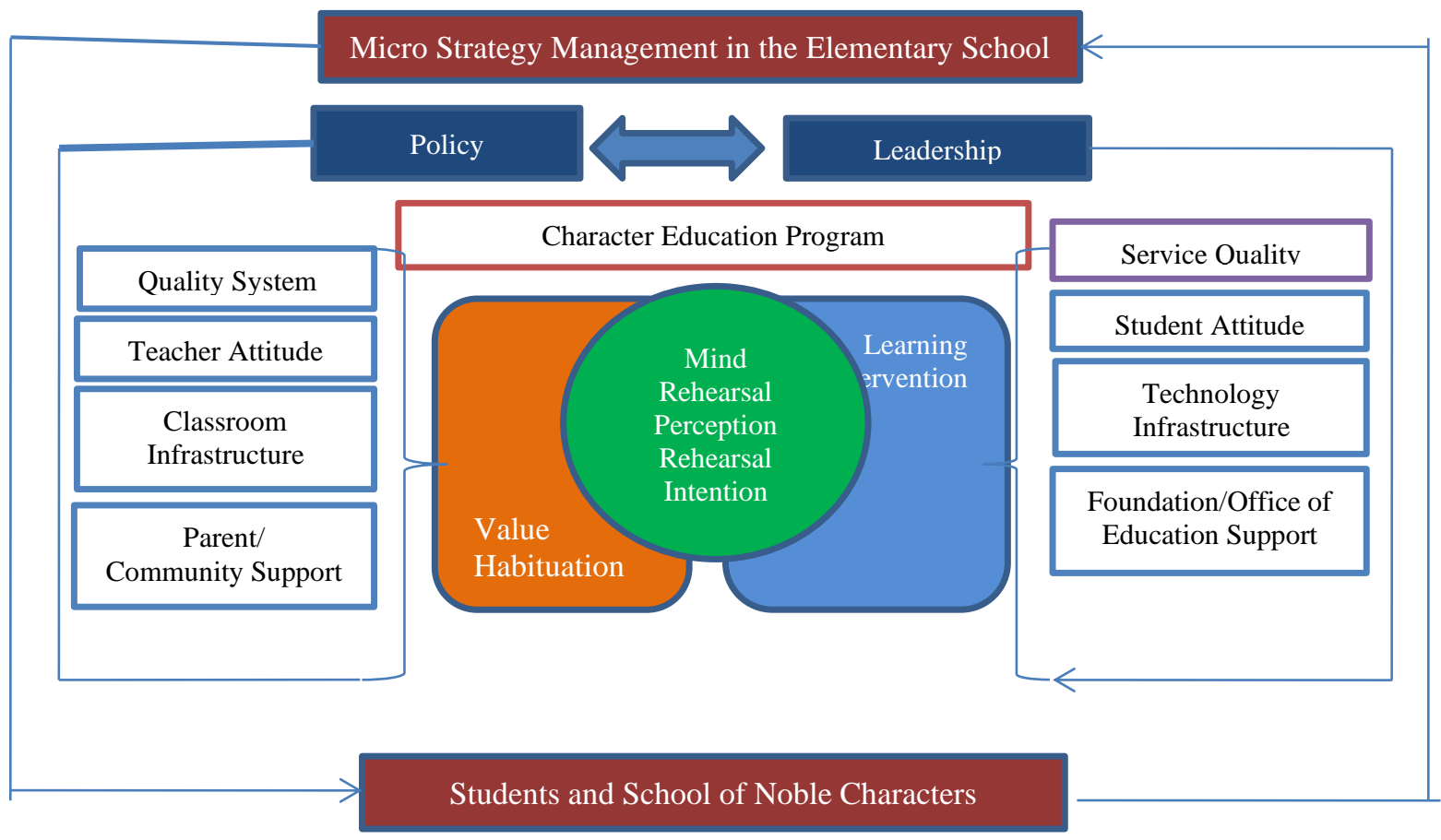

Figure 8. The integrative model of the micro strategy management for the character education in the elementary school

The implementation of the character education in the elementary school from the perspective of micro strategy should be approached in complete and integrative manner so that the model of micro strategy management framework that has been offered will contribute to the understanding of the school principal and the relevant institutions in relation to supporting the implementation of the character education in the elementary school. If the regional elementary schools are able to develop the healthy dynamics and competition in the local level, then these schools will also able to develop the constructive competitions in the domain of character development or, on the contrary, there will be another possibility that mutual suspicion has appeared to the surface (Kelly, 2007). The implication of the statement is that there will always be reports and maps of well-qualified characters from the school but the output and the outcome from the educational domain do not show any significant quality improvement. For example, the results of PISA in 2018 has placed the capacity of the Indonesian students in the rank $70^{\text {th }}$ out of 78 countries (Organization for Economic Co-operation and Development, 2019). With reference to the statement, it can be implied that the schools only pursue the aspects of competition for the sake of the market needs only so that the schools will always be favoured by the society. In other words, there is a pseudo-quality competition within the domain of education or between the status of the favorite school and the status of the non-favorite school whereas actually there has not been any significant difference between the favorite school and the non-favorite school in terms of academic culture. In other words, it is clear that the academic culture and the school quality in the regions share the homogenous quality condition. Usually, the curriculum innovation is determined by financial availability within the elementary school. On the other hand, conceptually the micro strategy management system for the character education can be developed by relying on the integrative construction and this system can be consulted in Figure 8.

\section{Conclusions}

The micro strategy management at the level of learning process and the reinforcement of the character values in the SDN 07 Sintang has been focused on the four main activities namely: (1) the literacy programs as the elementary school's efforts in building and improving the students' intelligence; and (2) the learning intervention programs as the school's efforts in improving the students' prominent characters through the thematic learning innovation. With reference to the statement, the Ant Operation Movement serves as the school's effort in developing the students' special capacity or the students' talent and interest. Then, in order to reinforce the micro strategy management of the school principal's 
leadership, the literacy programs should be expanded on the substances of the literacy such as art literacy, literature literacy, history literacy, science and digital literacy, or the virtual literacy through the implementation of the blended learning model and the more democratic classroom discussions (Parida et al., 2019a). At the same time, the micro-strategic management should be reinforced by improving the system management performance and the school network through the empowerment of the BRIGE Institution Australia in order to reach all teachers and students so that both the individuals and the institution can contribute the necessary talents for meeting the school needs (Parida et al., 2019b).

\section{References}

Alshamsi, S. M. (2017, December). Macro and micro leadership: The essential leadership role for sustanaibility of an organization. Skyline University College.

Ary, D., Jacobs, L. C., Irvine, C. K. S., \& Walker, D. (2018). Introduction to research in education. Cengage Learning.

Bamkin, S. (2016). Moral education at Japanese elementary school. Winston Churchill Memorial Trust. https://dora.dmu.ac.uk/handle/2086/13313

Barrett, G. F., \& Riddell, W. C. (2016). Ageing and literacy skills: Evidence from IALS, ALL and PIAAC (Issue 10017). IZA Discussion Paper.

Baxter, P., \& Jack, S. (2008). The qualitative report qualitative case study methodology: Study design and implementation for novice researchers. The Qualitative Report, 13(4), 544-559. https://nsuworks.nova.edu/\%0Atqr/vol13/iss4/2

Blaine, A. M. (2019). Interaction and presence in the virtual classroom: An analysis of the perceptions of students and teachers in online and blended Advanced Placement courses. Computers \& Education, 132, 31-43. https://doi.org/10.1016/j.compedu.2019.01.004

Denzin, N. K., \& Lincoln, Y. S. (2011). The Sage handbook of qualitative research. SAGE Publications.

Dike, D., \& Parida, L. (2016). Persepsi dan konsepsi mutu pendidikan sekolah dasar. Jurnal Pendidikan Dasar Perkhasa, 2(2), 197-211. https://doi.org/10.31932/jpdp.v2i2.112

Dike, D., \& Parida, L. (2019). Hexagonal management kelas dalam pembelajaran di sekolah dasar. Jurnal Akuntabilitas Manajemen Pendidikan, 7(1), 35-49. https://doi.org/10.21831/amp.v7i1.23268

Dyson, A., \& Millward, A. (2000). Schools and special needs. A Sage Publication Company.

Edarabia. (2019, January). 11 reasons why reading is important for children. Edarabia.Com, 1-3. https://www.edarabia.com/why-reading-important-children/

Gaskarth, J. (2012). The virtues in international society. European Journal of International Relations, 18(3), 431-453. https://doi.org/10.1177/1354066110389833

Gusarova, A. (2015). "Performance" and "Morality" as main goals of elementary schools in Japan. Procedia - Social and Behavioral Sciences, 182, 692-694. https://doi.org/10.1016/j.sbspro.2015.04.814

Hilliard, A. T. (2015). Global blended learning practices for teaching and learning, leadership, and professional development. Journal of International Education Research (JIER), 11(3), 179-188. https://doi.org/10.19030/jier.v11i3.9369

Hudha, M. N., Triwahyuningtyas, D., Rafikayati, A., Fajaruddin, S., Maryani, I., Widiaty, I., Nandiyanto, A. B. D., Hamidah, I., \& Permanasari, A. (2019). How is STEM learning for children with special needs in Indonesia? Journal of Physics: Conference Series, 1402, 044104. https://doi.org/10.1088/1742-6596/1402/4/044104

Kelly, A. (2007). School choice and student well-being. Palgrave Macmillan UK. https://doi.org/10.1057/9780230590281

Kostelnik, M. J., Gregory, K. M., Soderman, A. K., \& Whiren, A. P. (2012). Guiding children's: Social development and learning (7th ed.). Wadsworth Cengage Learning.

Kyosoku, S., \& Sei, G. (2009). Moral education at Japan elementary school (pp. 1-11). 
Masino, S., \& Niño-Zarazúa, M. (2016). What works to improve the quality of student learning in developing countries? International Journal of Educational Development, 48, 53-65. https://doi.org/10.1016/j.ijedudev.2015.11.012

Masnur, M. (2017). Pengaruh SSP tematik terhadap peningkatkan karakter kejujuran dan disiplin peserta didik kelas I SD. Jurnal Prima Edukasia, 5(1), 79. https://doi.org/10.21831/jpe.v5i1.7745

Muryaningsih, S., \& Mustadi, A. (2015). Pengembangan RPP tematik-integratif untuk meningkatkan karakter kerja keras di kelas 1 SD N 2 Sokaraja Tengah. Jurnal Prima Edukasia, 3(2), 190. https://doi.org/10.21831/jpe.v3i2.6146

Olive, J. L. (2014). Reflecting on the tensions between emic and etic perspectives in life history research: Lessons learned. Forum Qualitative Sozialforschung, 15(2). https://doi.org/10.17169/fqs15.2.2072

Organization for Economic Co-operation and Development. (2019). PISA 2018 assessment and analytical framework. OECD. https://doi.org/10.1787/b25efab8-en

Ozkan, S., Koseler, R., \& Baykal, N. (2009). Evaluating learning management systems. Transforming Government: People, Process and Policy, 3(2), 111-130. https://doi.org/10.1108/17506160910960522

Parida, L., Sirhi, S., \& Dike, D. (2019a). Pola kepemimpinan kepala sekolah dalam penguatan karakter di sekolah dasar Kota Sintang Kalimantan Barat. Profesi Pendidikan Dasar, 1(2). https://doi.org/10.23917/ppd.v1i2.9159

Parida, L., Sirhi, S., \& Dike, D. (2019b). Habituasi karakter unggul siswa sekolah dasar melalui optimalisasi peran kepemimpinan kepala sekolah di Kabupaten Sintang. Prosiding Seminar Nasional Pagelaran Pendidikan Dasar Nasional (PPDN) 2019, 1(1), 199-215.

Qodriyah, S. H., \& Wangid, M. N. (2015). Pengembangan SSP tematik integratif untuk membangun karakter kejujuran dan kepedulian siswa SD kelas II. Jurnal Prima Edukasia, 3(2), 177. https://doi.org/10.21831/jpe.v3i2.7222

Ryan, K., \& Bohlin, K. E. (1999). Building characterin schools: Practical ways to bring moral instruction to life. John Wiley \& Sons, Inc.

Schulte, A. K. (2008). Seeking integrity in teacher education: Transforming student teachers, transforming my self. Springer Science \& Business Media.

Setyawan, W. W., \& Mustadi, A. (2015). Pengembangan SSP tematik-integratif untuk membangun karakter disiplin dan kreatif siswa kelas I SD. Jurnal Prima Edukasia, 3(1), 108-119. https://doi.org/10.21831/jpe.v3i1.4072

Spillane, J. P., Halverson, R., \& Diamond, J. B. (2001). Investigating school leadership practice: A distributed perspective. Educational Researcher, 30(3), 23-28. https://doi.org/10.3102/0013189X030003023

Stake, R. E. (2005). Qualitative case studies. In N. K. Denzin \& Y. S. Lincoln (Eds.), The Sage Handbook of Qualitative Research (pp. 443-466). SAGE Publications.

Tobin, J., Hsueh, Y., \& Karasawa, M. (2009). Preschool in three cultures revisited: China, Japan, and the United States. University of Chicago Press.

Yin, R. K. (2009). Case study research: Design and methods (5th ed.). Sage Publications, Inc.

Zbar, V., Marshall, G., \& Power, P. (2007). Better schools better teachers better results: A handbook for improved performance management in your school. In Better Schools Better Teachers Better Results: A Handbook for Improved Performance Management in Your School. Acer Press. https://search.informit.com.au/documentSummary;dn=755417327497448;res=IELHSS 